\title{
BUDGETARY POLICY OF LOCAL GOVERNMENT AND ITS IMPACT ON ENTREPRENEURSHIP
}

\author{
Tomasz Skica*, Anna Golejewska**, Jarosław Bielak***
}

\begin{abstract}
Background. Budgetary policy has an important contribution to creating a business-friendly climate and development of SMEs in a given area.

Research aims. This paper examines the impact of the local budgetary policy on the development of entrepreneurship in Poland in the years 2010-2015. For the purpose of the paper, entrepreneurship was defined as the number of newly registered economic entities divided by the number of persons of working age, and budgetary policy through revenue and expenditure structure of commune/municipality budgets regarding their economic characteristics. The analysis was carried out regarding communes/municipalities split by urban, rural, and urban-rural entities.
\end{abstract}

Methodology. The authors applied cluster analysis using the K-medoids algorithm. Applying the cluster analysis, 2 types of budgetary policy were determined in urban, 3 types in rural, and 2 types in urban-rural communes. For each type of identified budgetary policy the impact of selected variables on entrepreneurship was estimated using panel models with one and many explanatory variables. The parameters were estimated using groupwise weighted least squares for the panel data method.

Key findings. In most cases, the results confirmed a positive impact of own revenue, current expenditure, and investment expenditure on entrepreneurship. The strongest effect of the above-mentioned variables was reported for municipalities. A negative impact was noted for general subsidies and grants.

Keywords: local government, budgetary policy, entrepreneurship, panel models.

* Department of Finance, University of Information Technology and Management (UITM) in Rzeszow. Institute for Financial Research and Analyses (IFRA) in Rzeszow. E-mail: tskica@wsiz.rzeszow.pl

** Faculty of Economics, Department of Economics of European Integration, University of Gdansk.E-mail: a.golejewska@ug.edu.pl

$* * *$ Department of Finance and Accounting, University of Management and Administration in Zamosc. E-mail: jbielak@wszia.edu.pl 


\section{INTRODUCTION}

Local economic development can be perceived in two ways: as a process of quantitative, qualitative and structural transformations of enterprises operating on a given territory and/or development of individual and collective entrepreneurship through ensuring the right conditions for their operations and the use of local resources, including institutional structures (Kogut-Jaworska, 2008). That means that local economic development is determined by cooperation of many entities: enterprises, business support institutions, and primarily local authorities.

The political changes of 1989 in Poland led to changes in the organisation of territorial self-government units. The result of decentralisation was not only the legal separation of a unit from a larger structure but also independence in making decisions and implementing tasks. Particularly, communes/municipalities have been equipped with tools to exert influence on local entrepreneurship which according to the commonly used definition of the European Commission means "a tendency to set up a new business, making new investments and creation of new jobs" (Postuła, 2008, p. 138). "Among the tools, major role play economic and financial instruments closely related to budgetary policy, concerning revenue and expenditure of a commune/municipality.

The main scope of the paper is to analyse the impact of local budgetary policy on development of entrepreneurship in Poland in the years 2010-2015. We attempt to assess the effectiveness of different types of local budgetary policy implemented in urban, rural, and urban-rural communes respectively in development of entrepreneurship, measured by an increase in the number of newly registered economic entities. Using panel models, we examine the impact of both budgetary policy as a whole and its individual components. An estimation of the models aims at finding those components of the budgetary policy which independent of the type of commune and the implemented budgetary policy have a positive or negative impact on entrepreneurship.

* Translation mine. 


\section{THEORETICAL BACKGROUND}

Local socio-economic development is a long, deliberate process of changes which are both quantitative and qualitative. The first group of changes includes among others an increase in budget revenues from local taxes, job and GDP growth, increase in revenue of enterprises, investment etc. Qualitative changes refer to modernization of the economy structure, the growth of the share of small and medium-sized enterprises in creating GDP, technological progress etc. (Sienkiewicz, 2014). Entrepreneurship determines innovation, job creation, and development as a whole. Economists carry out research on the mechanism that encourages greater entrepreneurship to find compatible economic policies. Business activity is influenced by a range of factors including those at national, regional and local levels. Therefore, activities vis-à-vis companies have to be carried out simultaneously at all levels. It is necessary to apply general instruments such as public finance reform, creation of a tax system promoting investments or elimination of bureaucratic constraints. Adequate actions should also be taken within the local level (Grodzka, 2008).

Since $1^{\text {st }}$ January 1999 Poland has a three-tier division of the state with local government units being the commune/municipality, district, and province. The responsibility of local authorities for local development has been increased, similarly to their autonomous discretionary power and competences to shape the financial policy. It is up to the local authorities to guarantee suitable conditions for economic development of the relevant territorial unit which requires creation of a favourable climate for enterprises. Local governments, especially communes/municipalities, are equipped with certain instruments serving this purpose. These include inter alia: possibility of developing programmes and strategies, budgeting, regulatory powers in the area of tax law and spatial planning. Ensuring economic growth is not only a statutory obligation on local authorities. It is also due to their reliance on revenues from income and corporation taxes. The amount of funds to be allocated to activities linked to the promotion of entrepreneurship depends on own revenues of a commune/municipality, composed mainly of various types of fees and taxes. In case of a designated subsidy there is no freedom in managing funds and in case of general subsidy, communes/municipalities formally are free to 
decide how to spend it, but a high share in this category is possessed by the educational part (Dziemianowicz et al., 2000).

Classifications of instruments at the disposal of the commune/ municipality and of relevance to the development of entrepreneurship are a subject of interest of many researchers (Okraszewska et al., 2002; Radacz, 2013; Zioło, 2012; Mickiewicz et al., 2016). Sienkiewicz divides them into three groups:

1) plans and programs run within the local area, included within a strategy document that is a local development strategy which is a base for such plans and strategies as land-use planning, environmental program, waste management plan, entrepreneurship development program etc.,

2) activities connected with infrastructural projects correlated with the investment plans of the municipality,

3) instruments of regulatory powers (i.e., orders, prohibitions, permits, or decisions) (Sienkiewicz, 2014).

According to Antoni Kożuch (2011), the instruments used by local governments can be divided into seven groups: legal and administrative, institutional, organisational, economic, financial, planning, and infrastructural. Janis Straumanis (2013) among the most important components of local economic policy indicates: local tax and duty policy, investment policy, territorial usage policy, policies for support, and development of administrative structures needed for implementation of the local economic policy (entrepreneurship support centres, business incubators, merchants' associations etc.) and project implementation programs for creating and developing the infrastructure. Dorota Grodzka (2008) classifies the support instruments employed by local units as follows:

1) plans and programmes of public tasks of a spatial, financial, and economic character,

2) regulatory instruments (obligations, prohibitions, permissions and decisions),

3) asset management (provision of land and municipal facilities, increase of property),

4) stimulus-economic instruments (e.g. differentiation of taxes and charges),

5) institutional instruments (establishment of organisational units focused on local economy development),

6) direct activities in the sphere of projects (e.g. construction of the infrastructure), 
7) information tools (e.g. providing databases for business units),

8) instruments of social policy including promotional activities.

Local support instruments can also be divided into:

1) financial (commune/municipality budget, investment expenditure etc.) and non-financial (local development strategy, commune/ municipality promotion, business support institutions etc.) (Flieger, 2009),

2) instruments influencing business units and environment of business units (Brol, 1997),

3) obligatory, legitimised by the law and optional initiated by local governments (Flieger, 2009), and

4) "soft" projects related to the development of human resources and "hard" projects related to the development of infrastructure (Skica et al., 2013, p. 11).

The budgetary policy implemented by revenues and expenditures has an important contribution to the creation of a business-friendly climate and development of SMEs in a given area has. Commonly used in the literature is the division of instruments into revenue and expenditure instruments (see Table 1).

Table 1. Examples of local revenue and expenditure instruments

\begin{tabular}{|c|c|}
\hline Revenue instruments & Expenditure instruments \\
\hline $\begin{array}{l}\text { - local tax and fee reductions } \\
\text { and preferences, in particular: } \\
\text { - preferential determination of rates } \\
\text { - total or partial exemptions from tax } \\
\text { - subjective individual discretionary } \\
\text { relief } \\
\text { - deferral of payment or instalment plan } \\
\text { - preferences in determining fees paid } \\
\text { by entrepreneurs to local budgets }\end{array}$ & $\begin{array}{l}\text { - investment increasing attractiveness } \\
\text { of the region } \\
\text { - support to activities of local institutions } \\
\text { of business supporting } \\
\text { - information and promotional instru- } \\
\text { ments (e.g. investor support centres) }\end{array}$ \\
\hline
\end{tabular}

Source: Kosiedowski, 2005, p. 318.

Revenue instruments include all fiscal reductions or exonerations and reducing the maximum levels of local taxes, such as real estate tax, tax on means of transportation, agricultural, and forestry tax, etc. Reduction of the tax burden is a passive instrument for supporting local entrepreneurship. Using this instrument a given commune/municipality leaves some funds in an enterprise which can be invested in its development or development of local infrastructure (Dziemianowicz et al., 2000). Local policy supporting entrepreneurship starts with 
setting tax rates which can be higher or lower than those set by the Ministry of Finance (Dziemianowicz et al., 2000). However, applying exemptions and tax rebates should be well thought out in terms of budget effectiveness. Particularly in the case of big foreign investors, reductions of real estate tax may cause important loss of revenue for the local budget. Apart from reductions, communes/municipalities may defer, remit, divide into instalments or abandon collection of fees and taxes constituting their revenues. According to some authors, stimulators based on local fee policy are more effective than instruments based on local taxes (Mickiewicz et al., 2016). However, from the entrepreneurs' perspective the most important thing is not the level of tax rates, but the stability and transparency of fiscal solutions (Flieger, 2009; Gancarczyk \& Gancarczyk, 2008; Dziemianowicz et al., 2000; Bończak-Kucharczyk et al., 1998). Enterprises planning their future activity need legal stability.

Expenditure instruments, regarded as more effective than revenue instruments, are more numerous than the latter. As the most important should be considered investments which - if well targeted - enhance investment attractiveness of a commune/municipality. Essential for companies investments in infrastructure can be divided into investment in technical infrastructure (transportation network, media supply, preparing the land for investment), and investment in social infrastructure and development of the labour market (Skica et al., 2013). Besides pure investment expenditures, communes/municipalities may dispose a part of their budgets on institutions promoting economic development, such as regional and local development agencies, business incubators, technology parks, guarantee funds, etc. The size of government, specifically the size of government spending, may have a negative relationship with entrepreneurship (Aidis et al., 2012). Firstly, high spending can indicate the level of government involvement in the economy suggesting overbearing regulations imposed by the government and thus discouraging entrepreneurship. Secondly, higher total spending, indicating greater social security and welfare, may raise the opportunity cost of entrepreneurship providing safety nets for potential entrepreneurs (Asif, 2015). Another example for the negative impact on entrepreneurial activity refers to private subsidies typically captured by large firms which benefit only small numbers of firms crowding out entrepreneurial activity. However, certain public goods may be of great importance for entrepreneurial activity (Tybout, 2000; Goedhuys \& Sleuwaegen, 2010). A good example can be the quality of the infrastructure, specifically 
transportation and communication which determines ease of access to the resources needed for start-ups (Asif, 2015).

The results of the empirical analysis confirm both the positive and negative impact of local budgetary policy on the development of entrepreneurship (Skica \& Wołowiec, 2013). The most popular subject of research is tax preferences. Some of the results confirm no or even a negative impact of taxation on economic activity (Levine \& Renelt, 1992; Bassanini \& Scarpetta, 2001). The review of selected research findings on the role of the local budgetary policy in development of entrepreneurship in Polish communes/municipalities is presented in Table 2.

Table 2. Selected research findings on the role of local budgetary policy in development of entrepreneurship in Poland

\begin{tabular}{|c|c|}
\hline Author (year) & Main findings \\
\hline $\begin{array}{l}\text { Mickiewicz et } \\
\text { al. (2016) }\end{array}$ & $\begin{array}{l}\text { The analysis covers } 731 \text { out of } 886 \text { randomly selected communes/ } \\
\text { municipalities. The level of entrepreneurship is determined by local } \\
\text { business and non-governmental organisations, and by active policy } \\
\text { to gain investors. The share of investment areas in the urban man- } \\
\text { agement plan, advice to the entrepreneurs and user-friendly financial } \\
\text { instruments are important for communes/municipalities with a low } \\
\text { level of entrepreneurship. For commercial activity the policy of com- } \\
\text { munes/municipalities is not very important. Of particular significance } \\
\text { for hotels and restaurants are financial instruments and for construc- } \\
\text { tion and manufacturing, beside social self-organization, public private } \\
\text { partnership }\end{array}$ \\
\hline $\begin{array}{l}\text { Bieńkowska } \\
\text { (2013) }\end{array}$ & $\begin{array}{l}\text { The results of the survey carried out on rural communes/municipalities } \\
\text { of the Mazovia Province showed that local investments contribute to } \\
\text { the attractiveness of the area for potential entrepreneurs. The com- } \\
\text { munes/municipalities with the lowest level of local development often } \\
\text { focus on training of entrepreneurs and supporting local leaders rather } \\
\text { than the communes/municipalities with a higher level of development. } \\
\text { The latter more often undertake actions to improve infrastructure } \\
\text { (repair of roads, water supply, etc.) and technology. The communes/mu- } \\
\text { nicipalities do not differ significantly in terms of applicable tax reliefs } \\
\text { and exemptions }\end{array}$ \\
\hline $\begin{array}{l}\text { Skica \& } \\
\text { Wołowiec } \\
\text { (2013) }\end{array}$ & $\begin{array}{l}\text { The article analyses the Podkarpackie Province communes/munic- } \\
\text { ipalities. Its results confirm that tax forms of support are of minor } \\
\text { importance for location of economic activity compared with better } \\
\text { infrastructure conditions, selection of areas for investment, lease of } \\
\text { commune facilities for economic activities, creation of capital back-up } \\
\text { comprised of loan funds and organisational changes aiming at better } \\
\text { efficiency of the office }\end{array}$ \\
\hline Flieger (2009) & $\begin{array}{l}\text { As the most effective financial instruments have been considered: tax } \\
\text { relief and tax exemption on properties, investment plots prepared for } \\
\text { business ventures, lower than the maximum tax rates on transport } \\
\text { means and road investments. As the most effective non-financial in- } \\
\text { struments were indicated inter alia, stable tax policy and easy access to } \\
\text { technical infrastructure }\end{array}$ \\
\hline
\end{tabular}




\begin{tabular}{|c|c|}
\hline Author (year) & Main findings \\
\hline Skica (2008) & $\begin{array}{l}\text { The analysis covers } 61 \text { Podkarpackie Province communes/municipali- } \\
\text { ties. According to the results, the nature and extent of applied instru- } \\
\text { ments for the promotion of entrepreneurship resulted from all types } \\
\text { of the communes/municipalities (urban, rural and urban-rural) and } \\
\text { its size. Their effectiveness depended on the specificity of the forms of } \\
\text { support. Most frequently the instruments were applied by municipali- } \\
\text { ties and cities with district rights. The communes/municipalities more } \\
\text { frequently used revenue - than expenditure instruments, however } \\
\text { the impact of the latter was stronger. Moreover, their application was } \\
\text { reflected in the establishment and the functioning of business-related } \\
\text { organisations and non-governmental organisations. It was also con- } \\
\text { firmed that a good condition of the infrastructure determines location } \\
\text { of operators. The majority of the communes/municipalities did not have } \\
\text { a special programme for supporting entrepreneurship and actions on } \\
\text { these issues were focused on building up investment and development } \\
\text { strategies }\end{array}$ \\
\hline $\begin{array}{l}\text { Gancarczyk \& } \\
\text { Gancarczyk } \\
(2008)\end{array}$ & $\begin{array}{l}\text { The results of the research carried out on the sample of communes/mu- } \\
\text { nicipalities from the Lesser Poland Province confirmed that tax reliefs } \\
\text { are perceived as the most desired instrument by enterprises. As the } \\
\text { main barriers they indicate poor support policy for entrepreneurship } \\
\text { and underdeveloped infrastructure. The entrepreneurs expect first of } \\
\text { all a complex support policy, creation of entrepreneurship zones and } \\
\text { changes in fiscal policy as a whole which should become stable, trans- } \\
\text { parent and predictable }\end{array}$ \\
\hline $\begin{array}{l}\text { Słomińska } \\
\text { (2007) }\end{array}$ & $\begin{array}{l}\text { The analysis covering } 100 \text { commune/municipality offices from } 11 \text { prov- } \\
\text { inces was carried out in } 2005 \text { by the Institute for Internal Market and } \\
\text { Consumption. It was focused on determinants and initiatives of entre- } \\
\text { preneurship on local markets and instruments applied by communes/ } \\
\text { municipalities to stimulate development of those markets. The results } \\
\text { showed that the size of a commune/ municipality has impact on the } \\
\text { actions taken by it. Small communes/municipalities more frequently } \\
\text { use revenue instruments and big communes/municipalities - expend- } \\
\text { iture ones. Over the years, there have been signs of a tendency to } \\
\text { avoid instruments which reduce revenues to local budgets. Communes/ } \\
\text { municipalities more frequently take actions aimed at finding investors, } \\
\text { promoting commune/ municipality, separating of investment plots, } \\
\text { development of roads and creating guarantee funds. More than half } \\
\text { of the entrepreneurs recognised the interest of local authorities as not } \\
\text { sufficient. The highest level of dissatisfaction was recorded for the } \\
\text { group of micro-enterprises }\end{array}$ \\
\hline $\begin{array}{l}\text { Dziemianowicz } \\
\& \text { Jałowiecki } \\
(2004)\end{array}$ & $\begin{array}{l}\text { Essential and the most expected instruments for enterprises, both do- } \\
\text { mestic and foreign, are, in descending order of importance: tax reliefs, } \\
\text { development of technical infrastructure, local strategic development } \\
\text { plans, and social infrastructure }\end{array}$ \\
\hline
\end{tabular}

Source: own elaboration based on above mentioned literature and Skica et al., 2013.

Both wealthy and poor communes/municipalities may use practically the same instruments to stimulate entrepreneurship. The difference concerns the scale of the implemented instruments and financial and organisational involvement. For the wealthy communes/municipalities it should be definitely easier to implement different measures. Local governments have at their disposal a wide range of instruments 
stimulating entrepreneurship development but they do not often use them in a complex way. According to Skica, it is essential to combine "hard" and "soft" instruments together (Skica et al., 2013). The measures are quite rarely focused on a long term perspective because of the objective budget restriction (Piecuch, 2010). Relevant in this regard may be local development strategies which for some authors are the most important instruments for creating local economic development and the formulation of policy in this respect (Gawroński, 2010; Nowak \& Skotarczyk, 2010; Zalewski, 2007).

\section{DATA AND METHODS}

The study was based on the local authorities in Poland divided into three categories: municipal, urban-rural, and rural. The time interval adopted for the study covered the years 2010-2015 (inclusive), and the data were obtained from the Central Statistical Office of Poland Local Data Bank (LDB).

The explained variable was entrepreneurship, defined as the number of newly registered economic entities per 1,000 people in working age. The explanatory variables describing the budget policy of the communes/municipalities, were defined as data representing the income and expenses of the budgets of local governments. In the description of the budget policy of the communes/municipalities, we used the following variables:

1) total revenue of the commune/municipality per capita (in PLN);

2) own revenue of commune/municipality per capita (in PLN);

3) general subvention per capita (in PLN);

4) total grants per capita (in PLN);

5) total expenditures per capita (in PLN);

6) investment expenditures per capita (in PLN);

7) current expenditures per capita (in PLN);

8) expenditures per capita (in PLN) according to separate departments of budget classification:

- 010 - agriculture and hunting;

- 600 - transport and communications;

- 750 - public administration;

- 754 - public safety and fire care;

- 801 - education; 
- 851 - health care;

- 852 - social assistance;

- 900 - commune/municipal economy and environmental protection;

- 921 - culture and national heritage.*

\section{STATISTICAL ANALYSIS OF THE SOURCE MATERIAL, USED STATISTICAL METHODS, AND RESEARCH RESULTS}

The first step of the research was the statistical analysis, which - because of the large number of outliers and asymmetrically distributed data - was based on quartiles (Maronna et al., 2006). Given the relatively large number of outliers, we decided to remove from the analysis only those communes/municipalities for which the variables had extreme values. We removed also a commune/municipality with gaps and errors in the data. Finally, statistical testing and modelling was based on 2,420 communes/municipalities, including: 287 municipalities, 1,542 rural communes, and 591 urban-rural communes.

Using the Mann-Whitney U test (Wackerly et al., 2008), the authors checked if there were statistically significant differences between the generic categories (i.e., municipal, urban-rural, and rural) of communes/municipalities in total revenue per capita (see Tables 3a and $3 \mathrm{~b}$ ), total expenditures per capita (see Tables $4 \mathrm{a}$ and $4 \mathrm{~b}$ ), as well as the number of business entities per 1,000 inhabitants in working age (see Tables $5 \mathrm{a}$ and $5 \mathrm{~b}$ ), justify the separate analysis of the above mentioned categories of a local government unit.

Table 3a. Total revenue of the commune/municipality per capita in PLN (quartile for 2015)

\begin{tabular}{|l|c|c|c|}
\hline $\begin{array}{c}\text { Commune/municipality } \\
\text { category }\end{array}$ & Quartile 1 & Median & Quartile 3 \\
\hline Municipalities & $3,035.27$ & $3,322.18$ & $4,170.14$ \\
\hline Rural communes & $3,089.57$ & $3,372.69$ & $3,702.92$ \\
\hline Urban-rural communes & $2,995.43$ & $3,244.56$ & $3,621.97$ \\
\hline
\end{tabular}

Source: own elaboration.

* There are some more explanatory variables available at LDB, but due to a lot of missing observation records, we decided to exclude them from the analysis. 
Table 3b. The p-value Mann-Whitney U test for the differences between the total revenue of the commune/municipality per capita, in PLN (for 2015)

\begin{tabular}{|l|c|c|}
\hline $\begin{array}{c}\text { Commune/municipality } \\
\text { category }\end{array}$ & Urban communes & Rural communes \\
\hline Rural communes & $0.0274 \mathrm{a}$ & \\
\hline Urban-rural communes & $<0.0001$ & 0.0001 \\
\hline
\end{tabular}

an 2010-2014, the differences between urban communes and rural communes were small and statistically insignificant (the levels of significant differences were: $0.1977 ; 0.6105 ; 0.8047$; $0.8105 ; 0.5087$, respectively).

Source: own elaboration.

The Mann-Whitney U test proved that between urban-rural communes and municipalities as well as rural communes there were statistically significant differences from the point of view of the considered criterion (i.e., total revenues in the commune/municipality per capita).

Table 4a. Total expenditures of commune per capita in PLN (quartile for 2015)

\begin{tabular}{|l|c|c|c|}
\hline $\begin{array}{c}\text { Commune/municipality } \\
\text { category }\end{array}$ & Quartile 1 & Median & Quartile 3 \\
\hline Municipalities & $2,941.55$ & $3,268.09$ & $4,130.34$ \\
\hline Rural communes & $2,968.83$ & $3,268.88$ & $3,642.70$ \\
\hline Urban-rural communes & $2,892.42$ & $3,171.08$ & $3,535.29$ \\
\hline
\end{tabular}

Source: own elaboration.

Table 4b. The p-value Mann-Whitney U test for the differences between communes/municipalities in Total expenditures of the commune/municipality per capita in PLN (for 2015)

\begin{tabular}{|l|c|c|}
\hline $\begin{array}{l}\text { Commune/municipality } \\
\text { category }\end{array}$ & Urban communes & Rural communes \\
\hline Rural communes & $0.0274 \mathrm{a}$ & \\
\hline Urban-rural communes & $<0.0001$ & 0.0001 \\
\hline
\end{tabular}

${ }^{a}$ In 2010-2014, the differences between urban communes and rural communes were small and statistically insignificant (the levels of significant differences were: $0.1977 ; 0.6105 ; 0.8047$; $0.8105 ; 0.5087$, respectively).

Source: own elaboration.

The Mann-Whitney U test proved that between urban-rural communes and municipalities there were statistically significant differences from the point of view of the considered criterion (i.e., expenditures 
per capita). Moreover, the difference between municipalities and urban-rural communes are becoming clearer in the consecutive years.

Table 5a. The level of entrepreneurship, defined as the number of newly registered economic entities per 1,000 people in working age (for 2015)

\begin{tabular}{|l|c|c|c|}
\hline $\begin{array}{c}\text { Commune/municipality } \\
\text { category }\end{array}$ & Quartile 1 & Median & Quartile 3 \\
\hline Municipalities & 11.0353 & 13.1163 & 15.5510 \\
\hline Rural communes & 7.1022 & 9.0073 & 11.5304 \\
\hline Urban-rural communes & 8.9488 & 10.7439 & 13.1378 \\
\hline
\end{tabular}

Source: own elaboration.

Table 5b. The p-value Mann-Whitney U test for the difference between communes/municipalities in the level of entrepreneurship defined as the number of newly registered economic entities per 1,000 people in working age (for 2015)

\begin{tabular}{|l|c|c|}
\hline $\begin{array}{c}\text { Commune/municipality } \\
\text { category }\end{array}$ & Urban communes & Rural communes \\
\hline Rural communes & $<0.0001$ & - \\
\hline Urban-rural communes & $<0.0001$ & $<0.0001$ \\
\hline
\end{tabular}

Source: own elaboration.

Finally, in the case of the third of the studied comparative criteria, the Mann-Whitney U test proved that the differences between all three groups of communes were statistically significant. This confirmed the validity of the analysis separately for all categories: municipalities, urban-rural communes, and rural communes.

In the next step of research, using the K-medoids clustering method (Hastie et al., 2009; Kaufman \& Rousseeuw, 2005), the authors defined within of each generic group of communes/municipalities, subgroups based on the five-dimensional vector of variables, containing:

1) share of own revenue in total revenue (in \%),

2) share of general subvention in total revenue (in \%),

3) share of grants in total revenue (in \%),

4) share of investment expenditure in total expenditure (in \%),

5) share of current expenditure in total expenditure (in \%).

* Between 2010 and 2015, the levels of significant differences were consecutively: 0.1663 ; $0.0469 ; 0.0064 ; 0.0082 ; 0.0010 ; 0.00002$. 
In this way two clusters for municipalities (see Table 6 and Graph 1), three clusters for rural communes (see Table 7 and Graph 2) and once again two clusters for urban-rural communes (see Table 8 and Graph 3) were obtained. Moreover, for each of the commune/municipality category and its clusters, the authors assigned the distribution of expenditures according to its divisions. In this way the information about the main components of the budgetary policy at local level were obtained, that is: the sources of revenue (in division on own and external revenue), expenditure directions (in division on current and investment expenditures) as well as the economic characteristics of expenditures, described with the structure of budgetary classification. This way of presenting the variables (necessary to describe the budgetary policy of communes) allowed conducting an extended analysis. It gives an opportunity to check the level of the communes/municipalities' financial independency, the policy of the local authorities relating to the investments, while paying attention to the main directions of budgetary funds allocation.

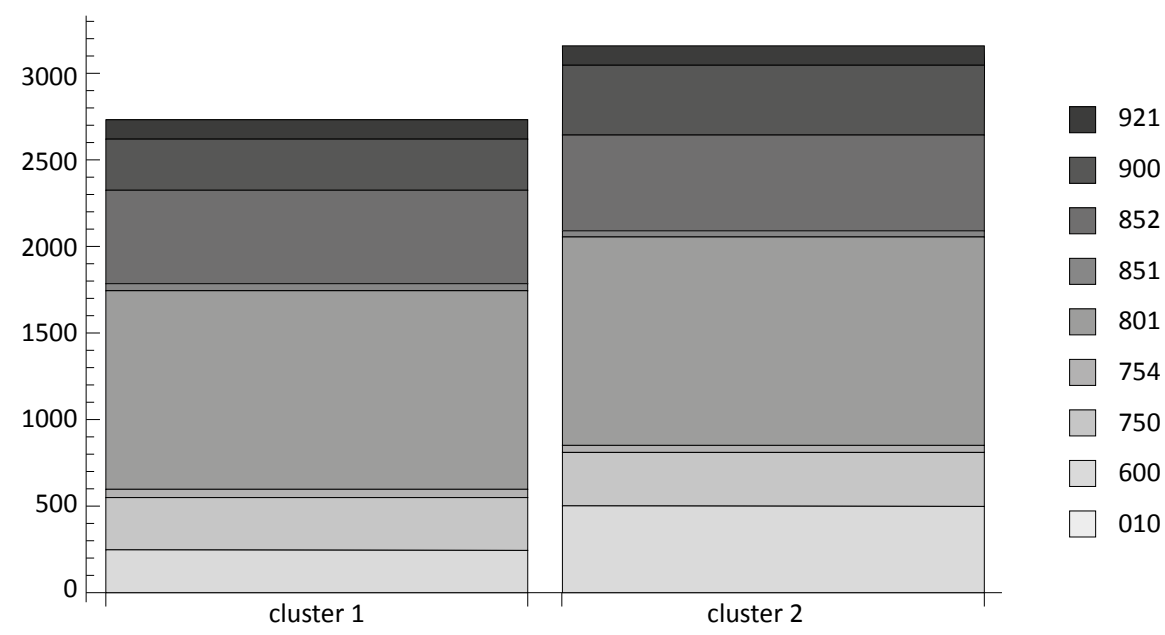

Graph 1. Clusters for municipalities

Source: own elaboration. 
Table 6. Clusterisation of municipalities from the point of view of the revenue and expenditure structure in 2015 in \% (medians), and the expenditure structure per capita in PLN (medians) in the division system

\begin{tabular}{|l|c|c|}
\hline \multicolumn{1}{|c|}{ Five-dimensional vector of variables (in \%) } & Cluster 1 & Cluster 2 \\
\hline Share of own revenue in total revenue & 61.1 & 52.6 \\
\hline Share of general subvention in total revenue & 21.4 & 22.4 \\
\hline Share of grants in total revenue & 17.1 & 23.5 \\
\hline Share of investment expenditure in total expenditure & 10.9 & 23.9 \\
\hline Share of current expenditure in total expenditure & 88.7 & 75.3 \\
\hline
\end{tabular}

Source: own elaboration.

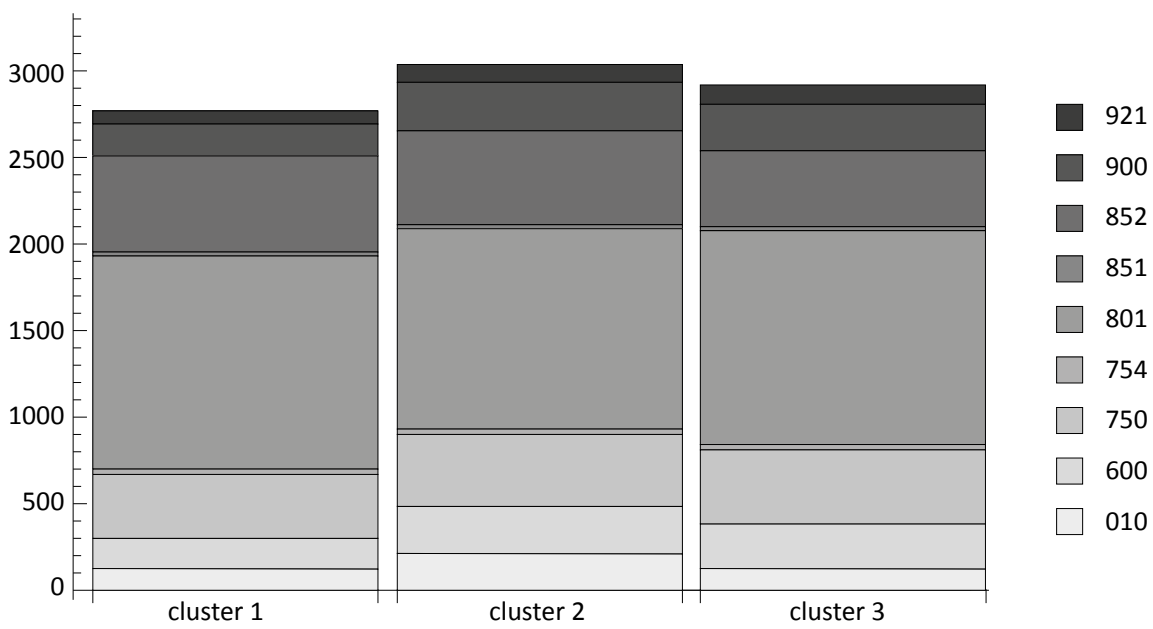

Graph 2. Clusters for rural communes

Source: own elaboration

Table 7. Clusterisation of rural communes from the point of view of the revenue and expenditure structure in 2015 in \% (medians), and the expenditure structure per capita in PLN (medians) in the division system

\begin{tabular}{|l|c|c|c|}
\hline \multicolumn{1}{|c|}{ Five-dimensional vector of variables (in \%) } & Cluster 1 & Cluster 2 & Cluster 3 \\
\hline Share of own revenue in total revenue & 33.5 & 32.9 & 55.2 \\
\hline Share of general subvention in total revenue & 42.1 & 33.7 & 25.6 \\
\hline Share of grants in total revenue & 24.10 & 32.3 & 18.2 \\
\hline Share of investment expenditure in total expenditure & 11.0 & 27.5 & 16.5 \\
\hline Share of current expenditure in total expenditure & 88.8 & 72.3 & 83.1 \\
\hline
\end{tabular}

Source: own elaboration. 


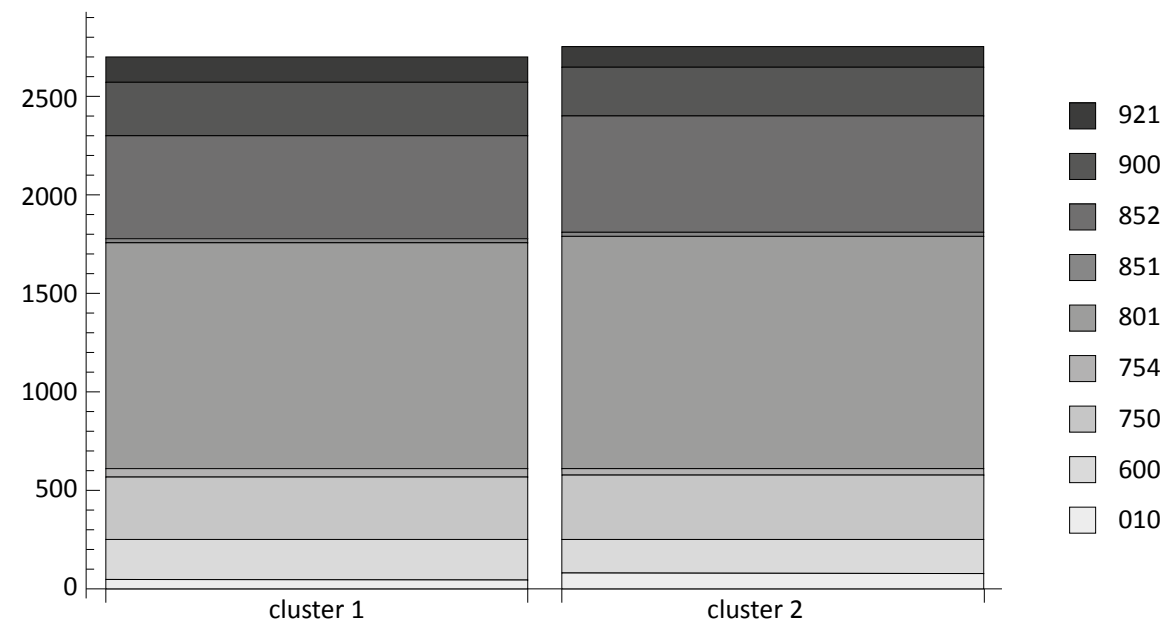

Graph 3. Clusters for urban-rural communes

Source: own elaboration.

Table 8. Clusterisation of urban-rural communes from the point of view of the revenue and expenditure structure in 2015 in \% (medians), and the expenditure structure per capita in PLN (medians) in the division system

\begin{tabular}{|l|c|c|}
\hline \multicolumn{1}{|c|}{ Five-dimensional vector of variables (in \%) } & Cluster 1 & Cluster 2 \\
\hline Share of own revenue in total revenue & 55.4 & 37.8 \\
\hline Share of general subvention in total revenue & 24.5 & 37.0 \\
\hline Share of grants in total revenue & 19.5 & 25.0 \\
\hline Share of investment expenditure in total expenditure & 13.7 & 12.2 \\
\hline Share of current expenditure in total expenditure & 85.8 & 87.6 \\
\hline
\end{tabular}

Source: own elaboration.

As a result of clusterisation the authors revealed various types of budget policies. Each type of budgetary policy has different characteristics of revenue and expenditure, additionally strengthened by differentiation in the division's structure of current expenditures (Table 9).

The first type of the budgetary policy for municipalities is characterised by a bigger share of own revenue and the predominance of current expenditures over investment expenditures. In turn, the second type of budgetary policy for this local government category is characterized by a bigger level of subvention and grants in the structure of revenue, and at the same time bigger (than in the first type of the budgetary policy) 
Table 9. Budgetary policies for municipalities, rural communes, and urban-rural communes on the basis of median of newly registered economic entities in clusters (for 2015)

\begin{tabular}{|c|c|c|c|c|c|c|c|}
\hline Model of budgetary policy & 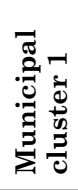 & 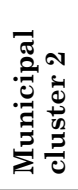 & 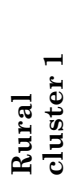 & 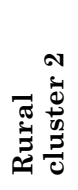 & 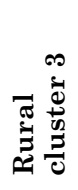 & 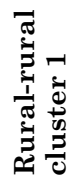 & 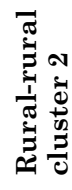 \\
\hline $\begin{array}{l}\text { Share of own revenue in total } \\
\text { revenue (in \%) }\end{array}$ & 61.1 & 52.6 & 32.5 & 33.5 & 53.3 & 55.4 & 37.8 \\
\hline $\begin{array}{l}\text { Share of general subvention } \\
\text { in total revenue (in \%) }\end{array}$ & 21.4 & 22.4 & 42.8 & 33.3 & 26.9 & 24.5 & 37.0 \\
\hline $\begin{array}{l}\text { Share of grants in total revenue } \\
\text { (in \%) }\end{array}$ & 17.1 & 23.5 & 24.4 & 32.4 & 18.5 & 19.5 & 25.0 \\
\hline $\begin{array}{l}\text { Share of investment expenditure } \\
\text { in total expenditure (in \%) }\end{array}$ & 10.9 & 23.9 & 11.1 & 28.3 & 15.9 & 13.7 & 12.2 \\
\hline $\begin{array}{l}\text { Share of current expenditure } \\
\text { in total expenditure (in \%) }\end{array}$ & 88.7 & 75.3 & 88.7 & 71.6 & 83.7 & 85.8 & 87.6 \\
\hline $\begin{array}{l}\text { Median of the number of newly } \\
\text { registered economic entities } \\
\text { in clusters }\end{array}$ & 12.9 & 13.8 & 8.3 & 8 & 11.1 & 12.0 & 9.8 \\
\hline
\end{tabular}

Source: own elaboration.

level of investment expenditures. The first type of the budgetary policy for rural communes describes governments with the lowest share of own revenues, the highest share of the subvention, and the lowest level of investments. The second type of the budgetary policy for the same category of communes/municipalities is characterised by uniform distribution of own revenue, general subvention, and grants. At the same time, they have got the highest level of investment expenditure. The third type of the budgetary policy of rural communes is characterised by the largest financial independence and the lowest share of grants in the structure of revenue. The expenditures are only slightly higher than the lowest level of investment activity (i.e., the first type of the budgetary policy). The first type of the budgetary policy for urban-rural communes is characterised by the predominance of own revenues, supplemented by the subvention. This type is characterized by higher investment expenditures than in the case of communes performing the second type of the budgetary policy, but still objectively a low level of investment activity. The second type of budgetary policy of urban-rural communes, mentioned before, describes a balanced distribution of 
incomes from own revenue and subventions supplemented by specific grants. The communes/municipalities, that implement this type of budgetary policy, are distinguished from urban-rural communities implementing the first type of the budgetary policy by a slightly lower level of investment activity.

\section{RESEARCH RESULTS}

On the basis of adopted assumptions and clusterisation of communes/ municipalities, the authors estimated panel models, explaining the impact of explanatory variables on entrepreneurship. Those models were divided into four groups (see Appendix, Tables from 10 to 13 inclusive). The first group consists of models with only one explanatory variable. Within these type of models, the authors checked the impact of a single explanatory variable (i.e., single element of the budgetary policy) on entrepreneurship, bypassing the expenditures divisions of the budgetary classification. In the second group of models, the effect of all of the explanatory variables (without expenditures classification into divisions) on the explained variable was studied. The third group was again models with only one explanatory variable, but this time using a single division of expenditure classification variables, through which the explained variable was examine. Finally, the fourth group consisted of models examining the explained variable, in the context of all of the divisions of expenditure classification explanatory variables.

Panel models with fixed time-effects were estimated via weighted least squares, with the weights based on the residual variance for the respective cross-sectional units (Mátyás \& Sevestre, 2008; Wooldridge, 2002) for each cluster of communes/municipalities separately. Given the fact, that the database contained pooled cross-sectional data, "simple" linear correlation coefficients (and the "classical" OLS estimation), between the variables was not appropriate in this case, because they can lead to incorrect conclusions. The panel models allowed considering (and eliminating) both the time effect changes in separate years, and variances within individual units (communes). As a result of the estimation, the obtained parameters were not biased by the above-mentioned "disturbances" (Greene, 2012; Hill et al., 2011, p. 537). 
An analysis of the results obtained by the models with one explanatory variable, skipping the division of the budget expenditures on sections of the budgetary classification, proves a positive relation between the total revenues as well as own revenues and entrepreneurship, in each category of the studied local governments, and in all types of budgetary policy. A negative relationship is observed between subvention and grants, and the dependent variable. An exception in the case of subventions and grants is the municipalities implementing the second type of budget policy, and in the case of grants also urban-rural communes implementing the second type of budgetary policy as well. A model with one explanatory variable also proved a positive relation between the total expenditures and entrepreneurship, and between - considered separately - investment expenditures as well as current expenditures and the level of entrepreneurship. The exception to all three categories of expenditures were urban-rural communes implementing the second type of budgetary policy, and in the case of investment expenditures additionally rural communes implementing the first type of budgetary policy.

The models with one explanatory variable that include the expenditure in divisions, prove - in general - the negative relation between an increase in expenditures in the divisions 010 (agriculture and hunting), 852 (social assistance) and 750 (public administration), and the number of newly registered business entities. An exception is the municipalities (for division 750 - leading the first and the second type of the budgetary policy, and for divisions 852 and 010 - leading the second type of the budgetary policy). The inverse situation is in the case of expenditures in divisions 851 (health care), 801 (education), and 921 (culture and national heritage). They are positively correlated with the level of entrepreneurship. The exception in division 801 are urban-rural communes implementing the second type of budgetary policy, and in division 921 the exceptions are urban-rural communes implementing the first type of budgetary policy. Expenditures in divisions 600 (transport and communication), 754 (public safety and fire care) and 900 (municipal economy and environmental protection) are also positively correlated with the level of entrepreneurship. The exception to this rule is the rural communes, implementing the first and the second type of budgetary policy for divisions 600 and 754, and in the case of division 900, the communes/municipalities implementing the first type of budgetary policy. 
In models with multiple explanatory variables, both excluding and including the structure of expenditure divisions, only statistically significant variables remained. The results of the estimation confirm the direction of the relations, identified by the models with one explanatory variable. Therefore, a positive relationship in the model with multiple explanatory variables concerns the impact of own revenue and current expenditures on the explained variable and it is typical of all of the categories of the studied local governments implementing all types of the budgetary policy. In turn, a negative impact on level of entrepreneurship is characterised by revenues in the form of: a general subvention (except municipalities implementing the second type of budgetary policy), grants (in all types of budgetary policy in rural communes and in the first type of budgetary policy in urban-rural communes), and investment expenditures (in the case of the first type of budgetary policy implemented by rural communes).

An analysis of models with multiple explanatory variables, taking into account the divisions of expenditures, confirms the results of estimation of models with one explanatory variable. Generally speaking, the expenditures in divisions: 750 (public administration) - with the exception of the municipalities, and 852 (social assistance) have a negative impact on the level of entrepreneurship. A positive impact on entrepreneurship is that of the expenditures in divisions: 600 (transport and communications) - with the exception of rural communes implementing the first type of budgetary policy, 851 (health care) and 921 (culture and national heritage), with the exception of urban-rural communes implementing the first type of budgetary policy.

\section{CONCLUSIONS}

The analysis proved the differences in the budgetary policies carried out by separate categories of communes/municiplaities, and pointed out differences in achieved effects. This fact is important, because it proves the differences in support potential between the communes/municipalities, as well as the efficiency of its use. The tools of the budgetary policy are in equal degree available to municipalities, rural, and urban-rural communes (its range and availability for the communes/municipalities is determined by the legislator), but effectiveness of these instruments depends on the budgetary policy implemented by each commune/ 
municipality separately. The effectiveness of the policy depends on authorities' ability to build it in a way that allows enlarging the existing potential through proper distribution of revenues and expenditures.

The estimation of panel models showed that among the constituent elements of the budgetary policy instruments can be extracted that independently of the type of commune and the type of budgetary policy impact in a positive way entrepreneurship, and elements with a negative impact on entrepreneurship. An example of the first policy are own revenues, which in the case of each category of commune/ municipality and each type of budgetary policy was characterised by positive correlation with the number of newly registered business entities. A completely different effect on entrepreneurship (with the exceptions described above), described the general subventions and grants representing external sources of revenue. The analysis of the expenditure side of the budgetary policies, that suggests a positive relationship between expenditures and entrepreneurship, should include not only the division on current and investment expenditures, but also take into account the destination of public funds. Estimations show that current expenditures were positively correlated with entrepreneurship in all categories of the local governments under study and in all types of budgetary policies. In the case of investment expenditures, estimations showed a negative correlation with newly registered entities, but only in the case of rural communes implementing the first type of budgetary policy. The presented results allow us to conclude that the most important part of an analysis is to check the structure of budgetary expenditures. Although the (absolute) values of the parameters are not large-assuming that there is a relationship between expenditures and the number of newly registered economic entities - in order to increase the number of companies per 1,000 inhabitants, we should increase spending a few hundred PLN on 1 person - it should be noted that the shown dependencies are highly significant at the significance level, in most cases, much less than 0.0001 . So it seems reasonable to conclude that revenues and expenditures in separate groups of communes/municipalities are associated with the number of newly registered business entities and some categories of expenditures do not contribute to the development of entrepreneurship.

The estimated models proved that expenditures focused on agriculture and hunting, as well as expenditures on social assistance are destimulants for entrepreneurship development. Public spending 
on public safety and public administration are also (in most cases), negatively correlated with the level of entrepreneurship expressed by the number of newly registered business entities. At the same time expenditures on education and health care bring positive effects for entrepreneurship. Expenditures on transport and communication as well as culture expenditures and national heritage expenditures bring not less favourable results.

\section{REFERENCES}

Aidis, R., Estrin, S., \& Mickiewicz, T. (2012). Size matters: Entrepreneurial entry and government. Small Business Economics, 39, 119-139.

Asif, I. (2015). Entrepreneurship and the allocation of government spending under imperfect markets. Development Economics Global Indicators Group Policy Research Working Paper, 7163, 1-24.

Bassanini, A. \& Scarpetta, S. (2001). The driving forces of economic growth: Panel data evidence for the OECD countries. OECD Economic Studies, 33(2), 9-56.

Bieńkowska, W. (2013). Activities of local authorities in promoting entrepreneurship in Poland. Economic Science for Rural Development, 32, 26-31.

Bończak-Kucharczyk, E., Herbst, K., \& Chmura, K. (1998). Jak wtadze lokalne moga wspierać przedsiębiorczość. Warszawa: Fundacja Inicjatyw Społeczno-Ekonomicznych, Polska Fundacja Promocji Małych i Średnich Przedsiębiorstw.

Brol, R. (1997). Rola i zadania samorządu i administracji w realizacji strategii rozwoju turystyki. In: M. Obrębalski (ed.). Gospodarka lokalna w teorii i praktyce, Wrocław: Akademia Ekonomiczna im. Oskara Langego.

Dziemianowicz, W. \& Jałowiecki, B. (2004). Bezpośrednie inwestycje zagraniczne a polityka miejska polskich metropolii. Warszawa: Wydawnictwo Naukowe Scholar.

Dziemianowicz, W., Mackiewicz, M., Malinowska, E., Misiag, W., \& Tomalak, M. (2000). Wspieranie przedsiębiorczości przez samorzad terytorialny. Warszawa: PAB-Font.

Flieger, M. (2009). Ocena gminnych instrumentów wspierania przedsiębiorczości. Ruch Prawniczy, Ekonomiczny $i$ Socjologiczny, 1, 147-167.

Gancarczyk, M. \& Gancarczyk, J. (2008). Czynniki rozwoju przedsiębiorczości w województwie małopolskim. Kraków: Urząd Marszałkowski Województwa Małopolskiego.

Gawroński, H. (2010). Zarzqdzanie strategiczne w samorzadach lokalnych. Warszawa: Oficyna a Wolters Kluwer business. 
Goedhuys, M. \& Sleuwaegen, L. (2010). High-growth entrepreneurial firms in Africa: A quantile regression approach. Small Business Economics, 34, 31-51.

Greene, W.H. (2012). Econometric Analysis, $7^{\text {th }}$ ed., Boston-London: Pearson.

Grodzka, D. (2008). Instrumenty wspierania działalności przedsiębiorstw przez jednostki samorządu terytorialnego. In: G. Gołębiowski, A. Zygierewicz (eds.), Wybrane problemy wspierania przedsiębiorstw w Polsce (pp. 111-134), Studia Biura Analiz Sejmowych Kancelarii Sejmu, no. 16, Warszawa: Biuro Analiz Sejmowych Kancelarii Sejmu.

Hastie, T., Tibshirani, R., \& Friedman, J.H. (2009). The Elements of Statistical Learning: Data Mining, Inference, and Prediction, $2^{\text {nd }}$ edition, Springer Series in Statistics, New York: Springer.

Hill, R.C., Griffiths, W.E., \& Lim, G.C. (2011). Principles of Econometrics, $4^{\text {th }}$ edition. Hoboken, NJ: Wiley.

Kaufman, L. \& Rousseeuw, P.J. (2005). Finding Groups in Data: An Introduction to Cluster Analysis, Wiley Series in Probability and Mathematical Statistics. Hoboken, N.J.: Wiley.

Kogut-Jaworska, M. (2008). Instrumenty interwencjonizmu lokalnego w stymulowaniu rozwoju gospodarczego. Warszawa: CeDeWu.

Kosiedowski, W. (ed.) (2005). Samorzqd terytorialny w procesie rozwoju regionalnego i lokalnego. Torun: Towarzystwo Naukowe Organizacji i Kierownictwa „Dom Organizatora”.

Kożuch, A. (2011). Rola samorządu terytorialnego we wspieraniu rozwoju lokalnego. In: A. Kożuch \& A. Noworól (eds.), Instrumenty zarzadzania rozwojem w przedsiębiorczych gminach, (pp. 9-26). Kraków: Instytut Spraw Publicznych.

Levine, R. \& Renelt, D. (1992). A sensitivity analysis of cross-country growth regressions. The American Economic Review, 84(4), 942-963.

Maronna, R.A., Yohai, V.J., \& Martin, R.D. (2006). Robust Statistics: Theory and Methods, Wiley Series in Probability and Statistics. Chichester: John Wiley \& Sons.

Mátyás, L. \& Sevestre, P. (2008). The Econometrics of Panel Data: Fundamentals and Recent Developments in Theory and Practice, $3^{\text {rd }}$ edition, Advanced Studies in Theoretical and Applied Econometrics. New York: Springer.

Mickiewicz, T., Rodzinka, J., \& Skica, T. (2016). Lokalne i regionalne czynniki wsparcia przedsiębiorczości. Klasteryzacja, promocja, doradztwo i lokalny kapitał społeczny. Warszawa: C.H. Beck.

Nowak, M.J. \& Skotarczyk, T. (eds.) (2010). Zarzadzanie miastem. Studium ekonomiczne i organizacyjne. Warszawa: CeDeWu. 
Okraszewska, A., Brzeziński, I., \& Kwiatkowski, J. (2002). Lokalny rozwój gospodarczy w kontekście wstapienia Polski do Unii Europejskiej. Warszawa: Fundacja Rozwoju Demokracji Lokalnej.

Piecuch, T. (2010). Przedsiębiorczość. Podstawy teoretyczne. Warszawa: C.H. Beck. Postuła, I. (2008). Regionalna pomoc publiczna jako determinanta rozwoju przedsiębiorczości. Problemy Zarzqdzania, 6(2), 137-153.

Radacz, J. (2013). Instrumenty wspierania przedsiębiorczości na przykładzie miasta Brodnicy. In: A. Jackiewicz \& Ł. Sułkowski (eds.), Dylematy rozwoju przedsiębiorczości w aspekcie regionalnym (pp. 345-364), Przedsiębiorczość $i$ Zarzadzanie, t. 14, z. 8, cz. 1. Łódź: Wydawnictwo Społecznej Akademii Nauk.

Sienkiewicz, M.W. (2014). Local economic development policy in Poland: Determinants and outcomes. Zbornik Radova Ekonomskog Fakulteta u Rijeci, 32(2), 405-427.

Skica, T. (2008). Instrumenty wspierania przedsiębiorczości przez samorząd terytorialny (na przykładzie gmin woj. Podkarpackiego). Samorzad Terytorialny, $1 / 2,43-62$.

Skica, T. \& Wołowiec, T. (2013). The instruments of stimulating entrepreneurship by local government units (lGU's). Ekonomska Istraživanja - Economic Research, 26(4), 127-146.

Skica, T., Bem, A., \& Daszyńska-Żygadło, K. (2013). The role of local government in the process of entrepreneurship development. Financial Internet Quarterly "e-Finanse", 9(4), 1-24.

Słomińska, B. (2007). Gmina w procesach stymulowania przedsiębiorczości. Samorzqd Terytorialny, 3, 19-33.

Straumanis, J. (2013). Local self-government initiatives and support opportunities for enterprises: The Sigulda County case. Social Research, 4(33), 25-35.

Tybout, J.R. (2000). Manufacturing firms in developing countries: How well do they do and why? Journal of Economic Literature, 38(1), 11-44.

Wackerly, D.D., Mendenhall, W., \& Scheaffer, R.L. (2008). Mathematical Statistics with Applications, $7^{\text {th }}$ edition, Belmont, CA: Thomson Brooks/Cole.

Wooldridge, J.M. (2002). Econometric Analysis of Cross Section and Panel Data. Cambridge, Mass.: MIT Press.

Zalewski, A. (ed.) (2007). Nowe zarzadzanie publiczne w polskim samorzadzie terytorialnym. Warszawa: Wydawnictwo SGH.

Zioło, M. (2012). Modele polityki inwestycyjnej gmin i ich wpływ na rozwój przedsiębiorczości. Zeszyty Naukowe Uniwersytetu Szczecińskiego. Ekonomiczne Problemy Ustug, 97(724), 283-296. 


\title{
POLITYKA BUDŻETOWA SAMORZĄDU LOKALNEGO I JEJ WPKYW NA PRZEDSIĘBIORCZOŚĆ
}

\begin{abstract}
Abstrakt
Tło badań. Polityka budżetowa ma istotny wkład w tworzenie klimatu sprzyjającego rozwojowi działalności gospodarczej na danym obszarze.

Cele badań. W artykule dokonano analizy wpływu lokalnej polityki budżetowej na rozwój przedsiębiorczości w Polsce w latach 2010-2015. Na potrzeby niniejszego artykułu przedsiębiorczość została zdefiniowana jako liczba nowo zarejestrowanych jednostek gospodarczych w przeliczeniu na liczbę osób w wieku produkcyjnym, a politykę budżetową określono przez pryzmat struktury dochodów i wydatków budżetów gminnych uwzględniający ich charakterystykę ekonomiczna. Analiza objęto gminy w podziale na jednostki miejskie, wiejskie i miejsko-wiejskie.
\end{abstract}

Metodologia. Autorzy zastosowali analizę skupień, wykorzystując algorytm oparty na medoidach. W wyniku przeprowadzonej analizy skupień zidentyfikowano dwa typy polityki budżetowej w gminach miejskich, trzy typy w gminach wiejskich i dwa w gminach miejsko-wiejskich. Dla każdego typu polityki wpływ poszczególnych zmiennych na przedsiębiorczość został oszacowany przy wykorzystaniu modeli panelowych z jedna i wieloma zmiennymi. Parametry modeli oszacowano za pomoca ważonej metody najmniejszych kwadratów dla danych panelowych.

Kluczowe wnioski. W większości przypadków wyniki potwierdziły pozytywny wpływ dochodów własnych, wydatków bieżących i wydatków inwestycyjnych na przedsiębiorczość. Najsilniejsze odziaływanie tych zmiennych zaobserwowano w gminach miejskich. Negatywny wpływ odnotowano w przypadku subwencji ogólnych i dotacji.

Słowa kluczowe: samorząd lokalny, polityka budżetowa, przedsiębiorczość, modele panelowe. 


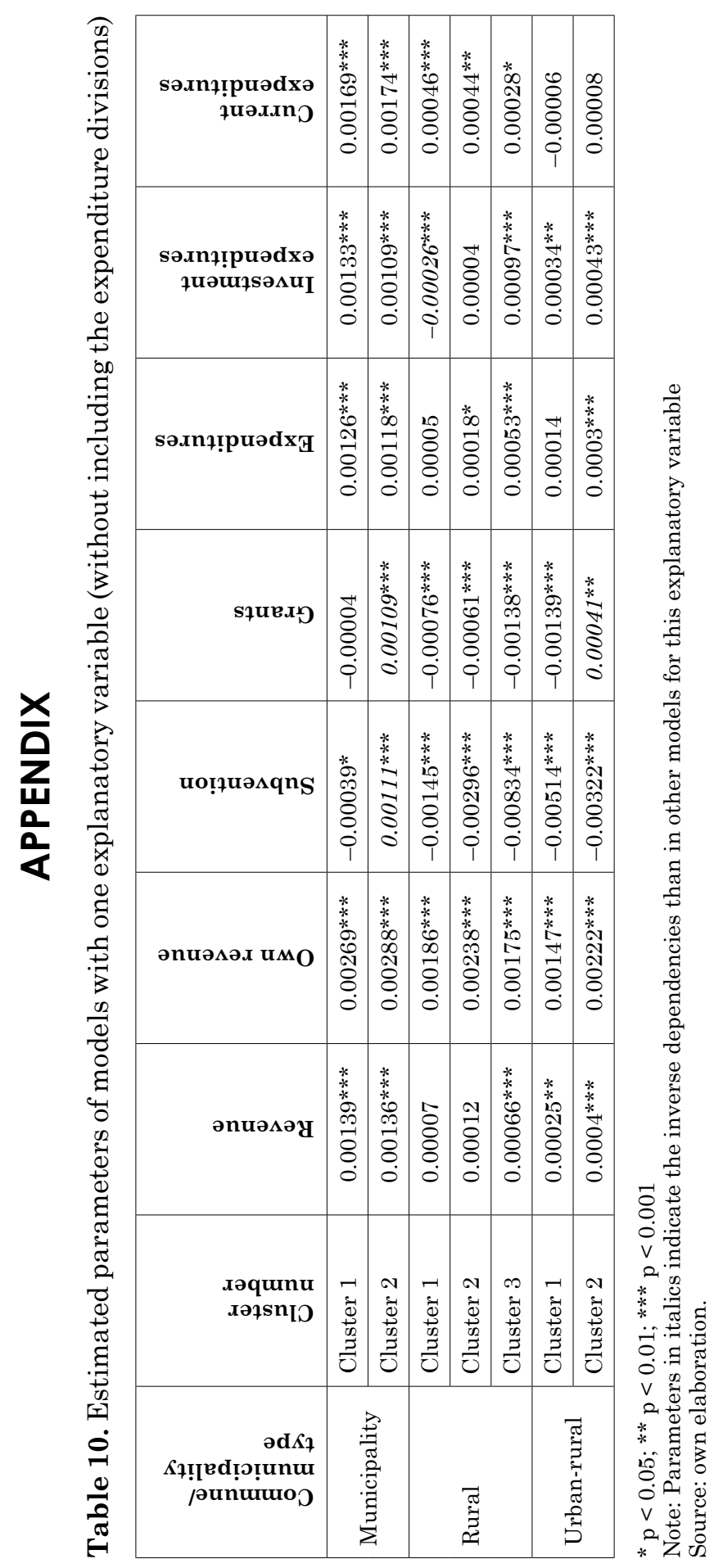




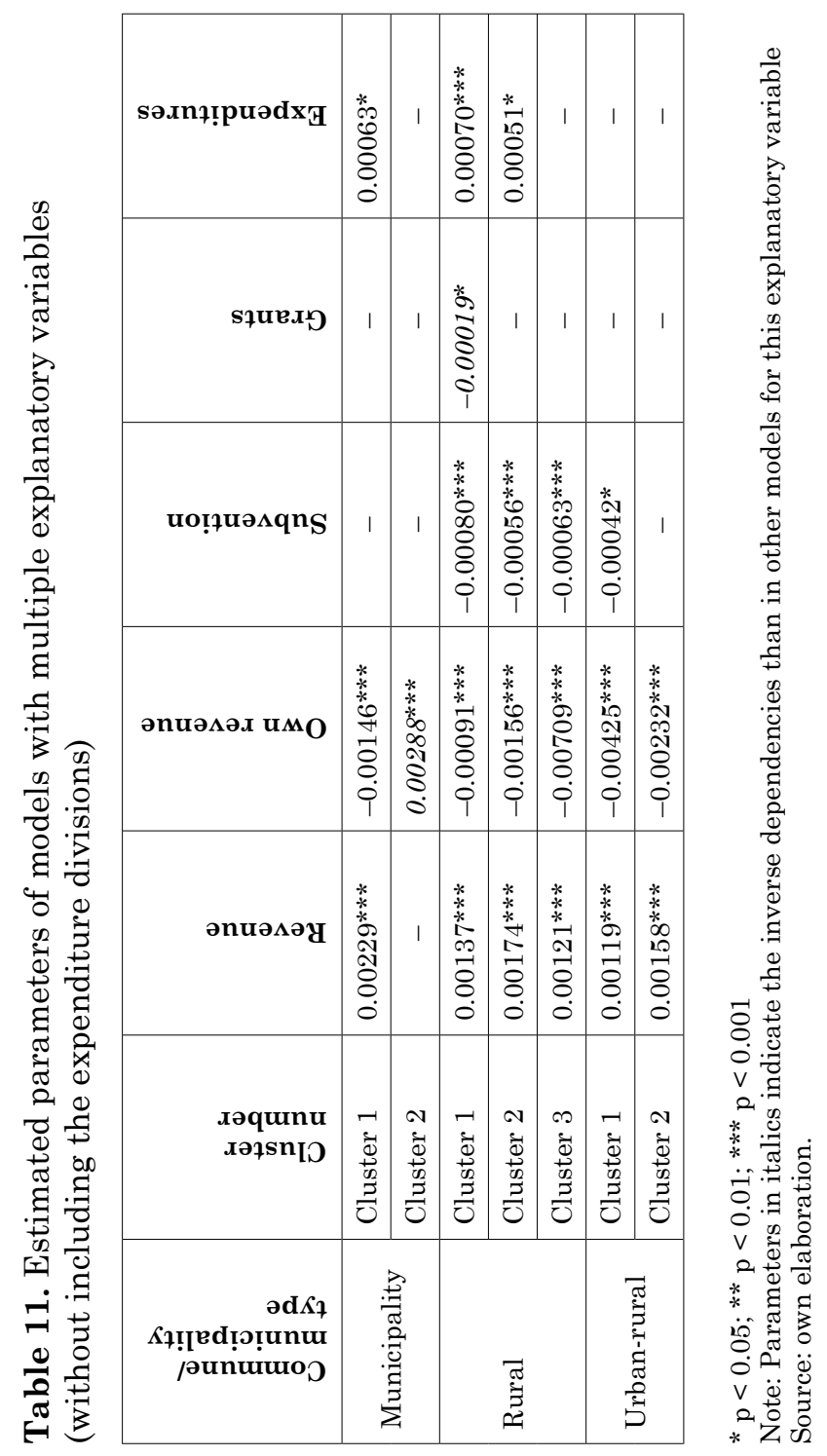




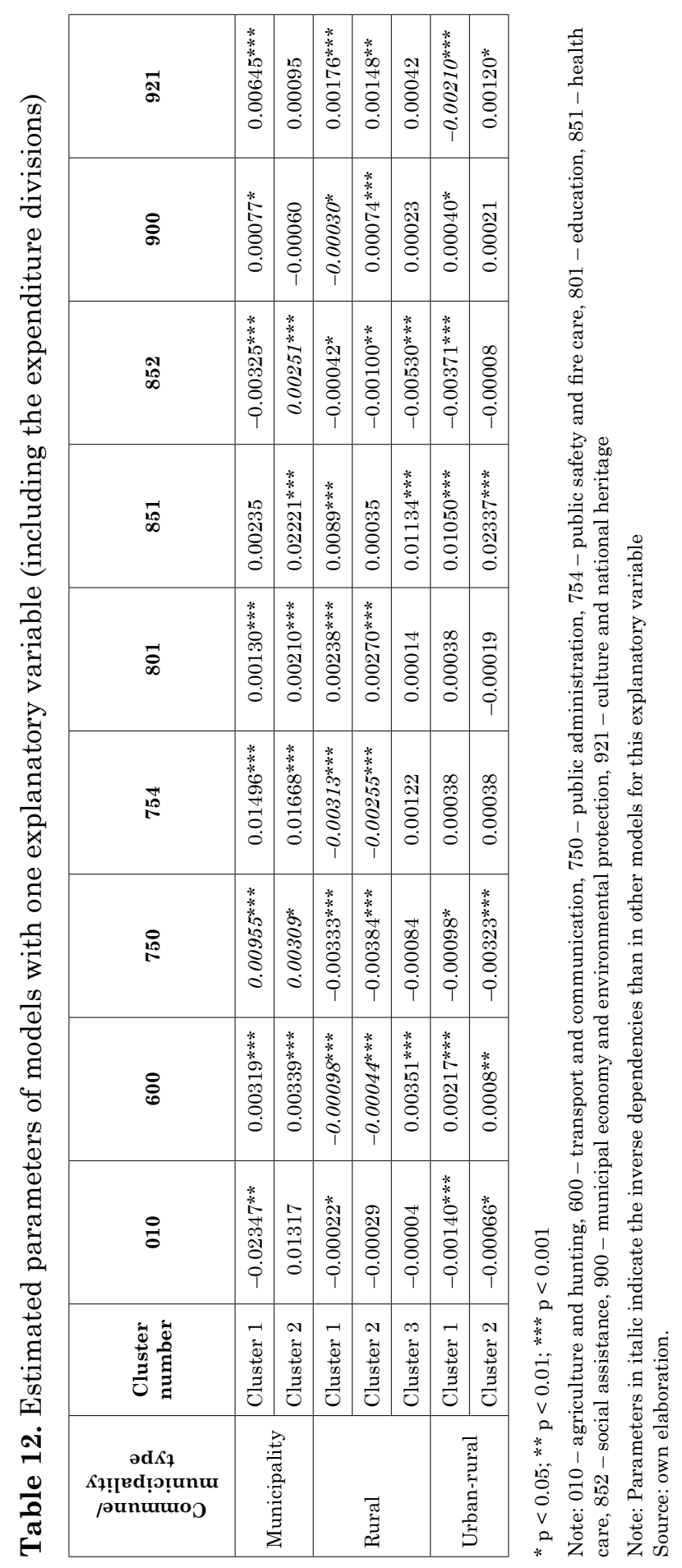




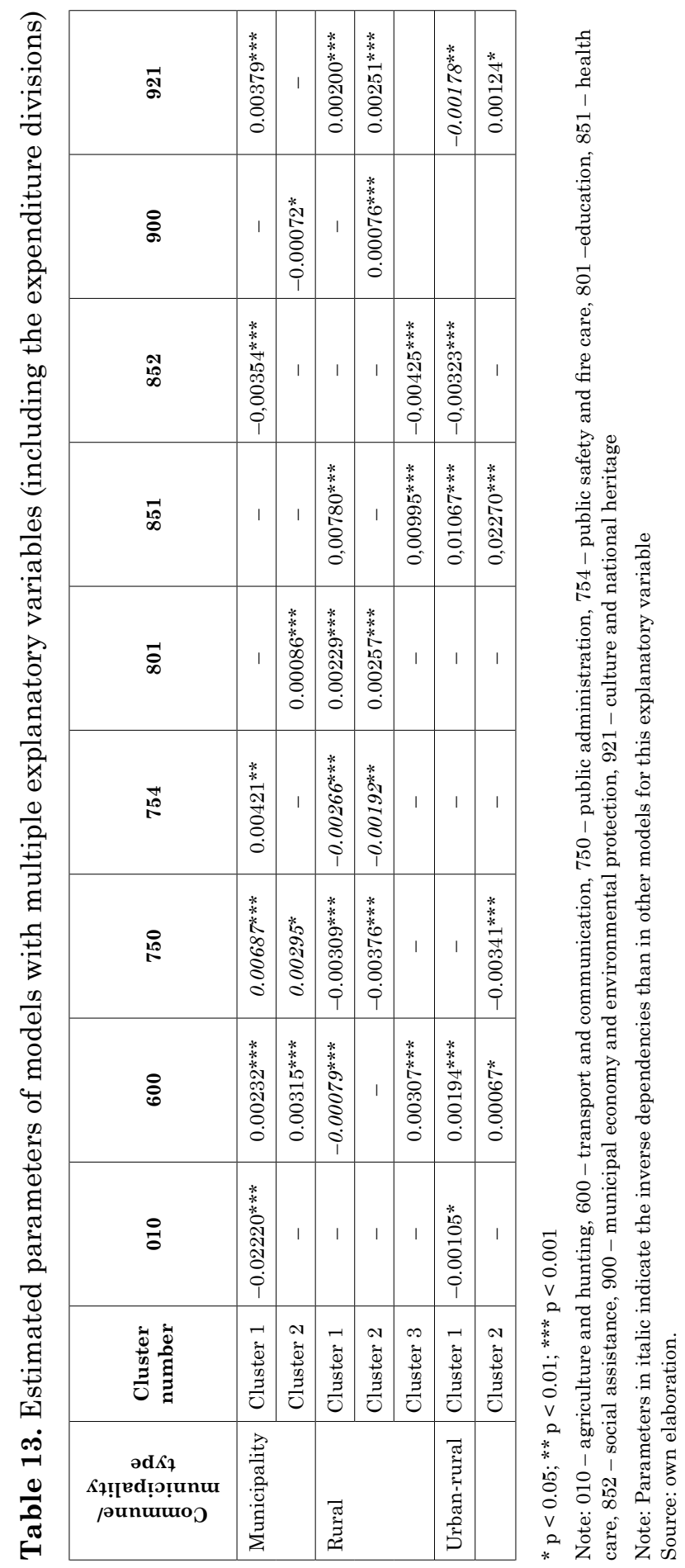

